\title{
Evaluating the influence of environmental factors on yearling Chinook salmon survival in the Columbia River plume (USA)
}

\author{
I. G. Brosnan ${ }^{1, *}$, D. W. Welch ${ }^{2}$, E. L. Rechisky ${ }^{2}$, A. D. Porter ${ }^{2}$ \\ ${ }^{1}$ Cornell University, 4122 Snee Hall, Ithaca, New York 14850, USA \\ ${ }^{2}$ Kintama Research Services, 10-1850 Northfield Road, Nanaimo, British Columbia V9S 3B3, Canada
}

\begin{abstract}
The impact of oceanographic processes on early marine survival of Pacific salmon is typically estimated upon adult return, 1 to $5 \mathrm{yr}$ after ocean entry, and many 1000s of kilometers after initial exposure. Here, we use direct estimates of early marine survival obtained from acoustic-tagged yearling Chinook salmon Oncorhynchus tshawytscha that entered the Columbia River plume (USA) after migrating down the river and then north to the coastal waters off Willapa Bay, Washington. Plume residence time averaged $7 \mathrm{~d}$, and was of such short duration that predation, rather than feeding and growth conditions, was the likely primary cause of mortality. Plume survival ranged from 0.13 to 0.86 , but was stable when scaled by plume residence time, and we find that a simple exponential decay model adequately describes plume survival. Plume survival, and perhaps adult returns, could be improved by reducing plume residence time if the drivers controlling residence time were amenable to management control. However, we show that a statistical model of plume residence time that includes only sea-surface temperature far outperforms models that include river discharge and coastal upwelling. Timing hatchery releases using marine environmental forecasts could potentially improve smolt survival by minimizing their residence time in regions of poor survival. Acoustic telemetry may be used to evaluate the value and effectiveness of such approaches.
\end{abstract}

KEY WORDS: Juvenile salmon - Juvenile survival - Columbia River plume - Acoustic telemetry · Environmental factors

Resale or republication not permitted without written consent of the publisher

\section{INTRODUCTION}

The Columbia River basin once supported large stocks of Pacific salmon, but their abundance has declined significantly under the combined effects of overfishing, damaging land-use practices, hydropower development, periodically unfavorable conditions for salmon survival in the North Pacific Ocean, and hatchery supplementation that accompanied the industrialization of the Pacific Northwest (National Research Council 1996, Mantua et al. 1997, Coronado \& Hilborn 1998). Since the passage of the Endangered Species Act in 1973, 5 of the 7 evolutionarily significant units (ESUs) of Chinook salmon Onco- rhynchus tshawytscha in the Columbia River basin have been listed as 'Threatened' or 'Endangered' and significant effort has been directed towards understanding the ocean ecology of salmon in the hopes of restoring depleted stocks (Brodeur et al. 2003, USNARA 2012).

Pearcy (1992) suggested that the number of juvenile salmon returning to spawn in their natal streams as adults may be established during the cohort's first month at sea, a 'critical period' of early marine survival. The possibility of predicting, and perhaps influencing, adult returns by elucidating the drivers of early marine survival has subsequently been an important focus for salmon ecologists. Numerous 
environmental variables have been examined for potential relationships with early marine survival. Although some variables lack clear mechanistic links to survival, they are generally related to feeding and growth opportunities, predation, and the effect of experiences in the river on subsequent fitness.

The annual transition to dominant northerly winds in spring, the 'spring transition', drives upwelling of cold nutrient-rich waters that support phytoplankton blooms and advect lipid-rich cold-water copepod species into the marine waters of Oregon and Washington, displacing relatively lipid-poor warm-water species and providing a food web input believed to be favorable for juvenile salmon growth (Huyer et al. 1979, Hickey \& Banas 2003, Peterson \& Keister 2003, Peterson \& Schwing 2003, Schwing et al. 2006). The timing of ocean entry of juvenile salmon relative to the spring transition has been proposed as a driver of early marine survival (Logerwell et al. 2003, Scheuerell et al. 2009; but see Tomaro et al. 2012).

DeRobertis et al. (2005) and Morgan et al. (2005), in companion papers, directly examined the potential relationships between feeding and survival by sampling juvenile salmon and their prey at tidally driven Columbia River plume fronts and in the adjoining plume waters and coastal ocean. They found that the fronts aggregate salmon prey, but found little evidence that juvenile salmon take advantage of the feeding opportunities at the fronts, potentially due to their ephemeral nature. While juvenile salmon may not take advantage of unique feeding advantages presented by the fronts, field sampling and bioenergetics modeling have indicated that they are not food limited in the plume region (Brodeur et al. 1992, Morgan et al. 2005).

Although they may not be food limited, juvenile salmon are subject to predation. Emmett et al. (2006) describe the seasonal migration of predatory Pacific hake Merluccius productus into coastal waters off the Columbia River and note that improvements in marine survival of juvenile salmon beginning in 1999 were coincident with a decrease in predator fish abundance. Emmett \& Sampson (2007) used a trophic model to demonstrate that high numbers of Pacific hake could account for high mortality of juvenile salmonids leaving the Columbia River. Collis et al. (2002) describe high and increasing proportions of juvenile salmonids in the diets of Caspian terns Sterna caspia and double-crested cormorants Phalacrocorax auritus from April into May. Colonies studied by Collis et al. (2002) on Rice Island in the midColumbia River were subsequently successfully encouraged to nest on East Sand Island (adjacent to the plume), reducing the proportion of their diet that consisted of juvenile salmon (Roby et al. 2002), but potentially increasing predation pressure in the plume. Turbidity in the plume may offer some relief as it has been shown to reduce predation on juvenile salmon (Gregory \& Levings 1998, DeRobertis et al. 2003), despite reducing predator avoidance behavior (Gregory 1993).

There may also be latent effects of the river experience on early marine survival; Budy et al. (2002) and Schaller \& Petrosky (2007) examined the effects of dam passage and concluded that there is evidence that the hydrosystem experience results in mortality that is delayed into early marine residence. Additionally, as a consequence of water being spilled over the dam faces (to reduce the physical and physiological stressors juveniles are exposed to during dam passage), air is entrained in the river, resulting in gas supersaturation below the dams. Exposure to supersaturated river water may result in gas bubble trauma in juvenile salmon (Bouck 1980), and, even when exposure is non-lethal, it may reduce their fitness and increase their susceptibility to predation (Mesa \& Warren 1997).

Other environmental variables that have been associated with early marine survival do not have mechanistic explanations as clear as those described above. Ryding \& Skalski (1999) and Cole (2000) linked survival with sea-surface temperature (SST), although when SST was examined in a suite of coastal oceanographic variables, including upwelling, wind mixing, mixed layer depth, sea level, and the timing of the spring transition, it was proven to be a dominant driver and is often an inconsistent predictor of adult returns (Hobday \& Boehlert 2001, Koslow et al. 2002, Scheuerell \& Williams 2005, Burke et al. 2013). Burla et al. (2010a) considered the effect of plume size and position, which are largely shaped by river discharge and wind-driven current, on juvenile survival and found no significant relationship with Chinook salmon returns and only a very weak relationship with steelhead salmon returns.

Here, we combine 2 novel approaches to gain insight into yearling Chinook survival in the Columbia River plume region, in their first period of marine residency. First, we use acoustic telemetry, which permits direct empirical measures of early marine survival to be evaluated against the environmental conditions experienced by tagged smolts (e.g. Rechisky et al. 2009, Moore et al. 2010, Welch et al. 2011, Thorstad et al. 2012, Melnychuk et al. 2013). This improves on the current approach to identifying critical environmental variables, which primarily 
relies on correlating them with smolt-toadult return rates estimated over 1 to $5 \mathrm{yr}$ and many 1000s of miles after exposure.

Second, we recognize that the plume is a region where occupancy is short and predators are rich, and thus it is conceivable that plume survival of telemetered smolts is regulated by their period of exposure (i.e. plume residence time) and that variables associated with survival, but lacking a direct link, may be acting on survival by influencing residence time. Therefore, in our analysis, we (1) evaluate the ability of a simple exponential decay model, equivalent to those used to model the decay of radioactive elements, to describe plume survival data for tagged yearling Chinook, (2) use the model residuals in survival analyses to examine whether measures of biological productivity or gas supersaturation levels, which may directly affect survival, would add additional predictive power to the model, and (3) evaluate the effect of 3 variables, potentially related to survival but lacking

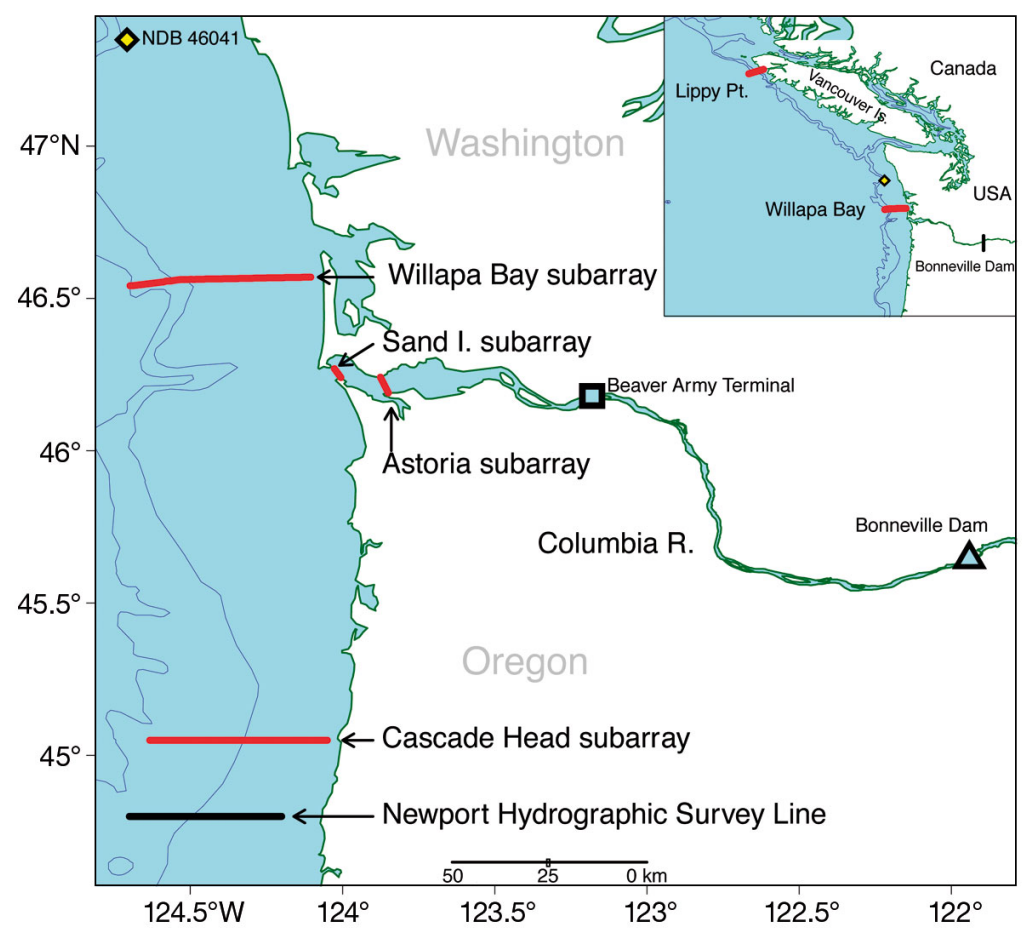

Fig. 1. Study region. The red lines mark the named telemetry sub-arrays. Contour lines mark the $200 \mathrm{~m}$ and $500 \mathrm{~m}$ isobaths clear mechanistic links, on plume residence time. These variables are SST, river discharge and wind-driven surface currents, the latter reflected in the coastal upwelling index. Finally, in light of our findings, we briefly discuss manipulating the dynamics of the Columbia River plume through flow control as a potential mechanism for improving plume survival of salmon (Jacobson et al. 2012).

\section{MATERIALS AND METHODS}

\section{Acoustic tagging and tracking}

From 2008 to 2011, yearling Chinook Oncorhynchus tshawytscha from the Columbia River basin were surgically implanted with uniquely coded VEMCO V7-2L $(7 \times 20 \mathrm{~mm}, 1.6 \mathrm{~g}$ in air, $69 \mathrm{kHz}$ transmission frequency) acoustic transmitters and then tracked as they migrated down the Columbia River and north along the continental shelf (Fig. 1). Yearling Chinook were used because several evolutionarily significant units in the Columbia River are listed as 'Threatened' or 'Endangered' under the USA Endangered Species Act and because their larger size reduces their tag burden. Although all groups of fish tagged and released for this study had a common migratory route in the lower river,

estuary, plume, and coastal ocean, they followed 3 different migratory paths to the lower river, depending upon their origin and handling. They include Columbia run-of-the-river (CR) groups, Snake runof-the-river (SR) groups, and Snake River transport (ST) groups (Table 1). In 2011, CR fish were identified as upper-Columbia (UC) or mid-Columbia (MC) using genetic stock identification (Table 1). Run-of-river groups were collected from hatcheries or at dams in their respective rivers, and then released to migrate to the ocean. Transported groups were collected from a hatchery or from Lower Granite Dam in the Snake River basin and then transported via truck or barge to below Bonneville Dam, the final dam on the Columbia River. With the exception of a unique early-April release of a group of transported fish in 2009, all releases occurred between late-April and late-May to minimize potential effects of emigration timing (Muir et al. 2006); release dates are reported in Table 1 . The methods summarized here are also available in uncondensed reports to the Bonneville Power Administration (Porter et al. 2009b, 2010, 2011, 2012a,b) and in Rechisky \& Welch (2010).

In 2008 and 2009, the CR groups were reared at the Cle Elum Supplementation and Research Facility on 
Table 1. Oncorhynchus tshawytscha. Group names, release dates, sample sizes, fork length (FL) range, proportion (\%) of the population represented by the size range tagged, and estimates of plume survival for acoustic-tagged Chinook smolts released in the Columbia (CR) and Snake Rivers (SR), or Snake River-sourced smolts that were transported and released below Bonneville Dam (ST). Chinook smolts released in the Columbia River in 2011 were identified as mid-Columbia (MC) or upperColumbia (UC) using genetic stock identification. The ST_09ER (early release) group, shown for reference, was excluded from the analysis

\begin{tabular}{|c|c|c|c|c|c|c|c|}
\hline Year & Group & Release dates & $\begin{array}{l}\text { No. of } \\
\text { fish }\end{array}$ & $\begin{array}{l}\text { FL range } \\
(\mathrm{mm})\end{array}$ & $\begin{array}{l}\text { Percent of } \\
\text { population }\end{array}$ & $\begin{array}{l}\text { Median plume } \\
\text { entry date }\end{array}$ & $\begin{array}{l}\text { Plume survival } \\
\text { (SE) }\end{array}$ \\
\hline \multirow[t]{3}{*}{2008} & SR_08 & 25 Apr \& 2 May & 395 & $130-159$ & 10 & 28 May & $0.41(0.07)$ \\
\hline & ST_08 & $17 \& 23$ May & 199 & $131-159$ & 10 & 26 May & $0.52(0.08)$ \\
\hline & CR_08 & 15 \& 21 May & 378 & $129-158$ & 72 & 29 May & $0.38(0.06)$ \\
\hline \multirow[t]{4}{*}{2009} & SR_09 & 4 \& 11 May & 389 & $130-164$ & 68 & 30 May & $0.53(0.16)$ \\
\hline & ST_09 & 27 May \& 3 Jun & 392 & $130-167$ & 68 & 31 May & $0.86(0.14)$ \\
\hline & ST_09ER & $17 \mathrm{Apr}$ & 196 & $130-10 t$ & 68 & 27 Apr & $0.78(0.15)$ \\
\hline & CR_09 & 18 \& 25 May & 393 & $130-159$ & 69 & 2 Jun & $0.36(0.12)$ \\
\hline \multirow[t]{3}{*}{2010} & SR_10 & 17-24 May & 383 & $130-167$ & 74 & 4 Jun & $0.69(0.11)$ \\
\hline & ST_10 & 18-26 May & 406 & $130-171$ & 74 & 27 May & $0.58(0.07)$ \\
\hline & CR_10 & 28 Apr-13 May & 790 & $130-215$ & 88 & 14 May & $0.41(0.05)$ \\
\hline \multirow[t]{4}{*}{2011} & SR_11 & 23 Apr-28 May & 80 & $132-168$ & 78 & 25 May & $0.25(0.07)$ \\
\hline & $\mathrm{ST} \_11$ & 3-22 May & 200 & $130-165$ & 71 & 24 May & $0.13(0.03)$ \\
\hline & UC_11 & 23 Apr-28 May & 386 & $130-170$ & 78 & 21 May & $0.31(0.04)$ \\
\hline & MC_11 & 23 Apr-28 May & 59 & $131-168$ & 74 & 11 May & $0.22(0.07)$ \\
\hline
\end{tabular}

the Yakima River (a tributary of the Columbia River), but were captured, tagged, and re-released in 2 sub-groups $6 \mathrm{~d}$ (2008) and $7 \mathrm{~d}$ (2009) apart at the downstream Chandler Juvenile Monitoring Facility (CJMF). This was done to avoid the significant mortality, and thus reduced sample size, that occurs between these 2 facilities (Yakima Nation 2011). The SR and ST groups consisted of yearling Chinook reared at the Dworshak National Fish Hatchery (DNFH) on the Clearwater River (a Snake River tributary). The SR groups were released upstream of DNFH in 2 sub-groups $7 \mathrm{~d}$ apart. The ST groups were trucked to Lower Granite Dam and then placed in a barge for transport and release below Bonneville Dam in 2 sub-groups $6 \mathrm{~d}$ apart. There was also a single early transport release in 2009 (ST_09ER).

In 2010, the CR group consisted of hatchery- and wild-origin smolts (62\% had fin clips) collected and tagged at the John Day Dam (Columbia River) before being released $42 \mathrm{~km}$ upstream in small sub-groups over 15 d. The Snake River groups consisted largely of hatchery-origin fish (97\% had fin clips) that were collected and tagged at Lower Granite Dam and released in the tailrace over $8 \mathrm{~d}$, or transported and released below Bonneville Dam in the lower Columbia River over 9 d. Unlike 2008, 2009, and 2011, the stocks of origin for fish tagged in 2010 are unknown. We have assumed that smolts collected at John Day Dam originated in the Columbia River (although some could be Snake River smolts) and those collected at Lower Granite Dam were of Snake River origin. We have also assumed that these fish are yearling Chinook, but since they were not known to be hatchery fish (as in 2008 to 2009) or genetically identified (as in 2011), it is possible that a proportion were hold-over fall type yearlings.

In 2011, juveniles in the CR and SR groups were captured and tagged at Bonneville Dam and then released in the tailrace over 14 and $7 \mathrm{~d}$, respectively. Genetic stock identification was used to distinguish the spring Snake, mid- and upper-Columbia smolts used in the analysis (Porter et al. 2012b). The ST group fish were collected at Lower Granite Dam and transported for release below Bonneville Dam in 2 groups $8 \mathrm{~d}$ apart.

The surgical protocol for implanting the VEMCO V7-2L acoustic tag included sedation, anesthetic induction, tagging, and recovery. Briefly, fish captured for tagging were allowed to acclimate to their holding tank, and food was withheld for approximately $24 \mathrm{~h}$ prior to surgery. Fish were sedated with a 20 ppm dose of tricaine methane sulphonate (TMS or MS-222), and anesthetic induction was accomplished in a bath containing $70 \mathrm{ppm}$ TMS. Once they reached Stage IV anesthesia, smolts were placed ventral side up, and their gills and mouths gently irrigated with a water tube. An incision to accommodate the tag was made on the mid-ventral line, and the tag was inserted into the abdominal cavity. Incisions were closed with sterile monofilament absorbable suture, and fish were transferred to a recovery tank for at least $24 \mathrm{~h}$ before release. 
Although this study focuses on survival in the plume region between the mouth of the Columbia River (Astoria, Oregon) and the coastal waters off Willapa Bay, Washington, the sub-arrays of acoustic receivers used to delineate the plume were part of a much larger array deployed within the Columbia River basin and eastern North Pacific coastal ocean. The Columbia River basin array elements were emplaced in 2006. However, we have used only the 2008 through 2011 data to build the models, as there was no sub-array at Astoria in 2006 to distinguish between survival in the lower river and the plume, and problems with smolt tagging precluded use of 2007 data (Porter et al. 2009a). Although lower river and plume survival were conflated in 2006 due to the lack of a sub-array at Astoria, we derived estimates of plume survival and residence time for 2006 using travel times and average survival between Bonneville Dam and Astoria from 2008 to 2011. The derived estimates were plotted against the exponential decay model output as an additional test of the model's adequacy.

\section{Environmental data}

Researchers have identified a number of environmental variables that may be related to the early marine survival of juvenile salmon. Using current literature as a guide, we identified 6 variables with publicly available datasets for exploratory analysis. These were timing of the biological spring transition (Koslow et al. 2002, Logerwell et al. 2003, Tomaro et al. 2012, Burke et al. 2013), cumulative upwelling prior to ocean entry (Schwing et al. 2006), turbidity (Gregory \& Levings 1998, DeRobertis et al. 2003), SST (Ryding \& Skalski 1999, Hobday \& Boehlert 2001, Koslow et al. 2002, Logerwell et al. 2003, Burke et al. 2013), and upwelling and river discharge (Budy et al. 2002, Schaller \& Petrosky 2007, Burla et al. 2010a). We lacked predator data, but hypothesized that if predation was the primary driver of survival, then survival could be related to period of exposure, i.e. plume residence time. Finally, flooding in the Columbia River basin in 2011 resulted in high levels of involuntary spill at Bonneville Dam, supersaturating the river below the dam with dissolved gas and raising our interest in the effect of physiological damage resulting from exposure to supersaturated water on subsequent plume survival (Mesa \&Warren 1997, Mesa et al. 2000, USACOE 2011). We performed an initial exploration of the data with pairwise plots and used Pearson correlation coefficients to identify strongly collinear variables (Pearson correlation coefficient $\geq 0.95$ ).

Coastal upwelling (UP), 2 and 4 wk cumulative upwelling (CU2, CU4). Daily upwelling index values at $48^{\circ} \mathrm{N}$ (cubic meters per second per 100 meters of coastline) were obtained from the NOAA Pacific Fisheries Environmental Laboratory (www.pfeg. noaa.gov/). Values were averaged over the period between plume entry and plume departure (see 'Analysis' section for how entry and departure dates were determined) for each salmon group in each year and cumulative upwelling was calculated for the 14 and $30 \mathrm{~d}$ periods prior to plume entry of each group in each year.

Biological spring transition (BST). We used transition dates for 2008 to 2011 that were calculated using the Peterson method and obtained through Columbia River Data Access in Real Time (DART; www.cbr. washington.edu/dart/). The Peterson method identifies the BST date as the day when cluster analysis of copepods sampled during biweekly research cruises at the hydrographic baseline station NH 05 off Newport, Oregon, indicates the transition from a southern, warm-water zooplankton assemblage to a northern, cold-water assemblage (Peterson \& Keister 2003, Peterson \& Schwing 2003, Hooff \& Peterson 2006, Peterson et al. 2006). The timing of ocean entry of the tagged smolts in relation to the spring transition was calculated by subtracting the date of the transition from the date of entry into the plume by each group in each year.

Lower river gas saturation (PDG). We obtained gas saturation data, measured as percent dissolved gas (PDG), from an automated US Army Corp of Engineers water quality monitoring station located at Camas, Washington/Washougal, Oregon (CWMW), $40 \mathrm{~km}$ downstream of Bonneville Dam (Fig. 1; www. cbr.washington.edu/dart/). Hourly values were averaged over the period between median arrival date on the acoustic sub-array below Bonneville Dam or release date at Bonneville Dam and the plume entry date for each salmon group in each year.

Sea-surface temperature (SST). $\mathrm{SST}\left({ }^{\circ} \mathrm{C}\right)$ is measured hourly at several NOAA data buoys (NDB) off the Columbia River. NDB 46041, located approximately $111 \mathrm{~km}$ northwest of the mouth of the Columbia River (Fig. 1), had a complete SST data set for periods when tagged juvenile salmon were transiting the plume (www.ndbc.noaa.gov/). Hourly values collected at this buoy were averaged over the period between plume entry and plume departure for each salmon group in each year.

River discharge (DIS). River discharge data are recorded at Beaver Army Terminal near Quincy, 
Oregon, $150 \mathrm{~km}$ downstream of Bonneville Dam (Fig. 1). This is the last discharge recording station in the Columbia River. Daily mean discharge is recorded in cubic feet per second (converted to cubic meters per second) and was extracted from the National Water Information System (http://waterdata.usgs.gov/). Daily values were averaged over the period between plume entry and plume departure for each group in each year.

Turbidity (TB). River turbidity is measured daily at Bonneville Dam in units of Secchi-feet (converted to Secchi-meters), and the data were accessed through Columbia River DART (www.cbr.washington.edu/ dart/). Bonneville Dam is located at River Mile 146.1, well upstream of the plume, but it is the closest continuous measurement of turbidity available. Turbidity in the plume should lag turbidity measured at Bonneville, with the lag time dependent on discharge levels. To estimate lag times for each group, we used the difference between their median arrival date at Astoria and median arrival, or release, date at Bonneville. Based on previous studies correlating juvenile travel time and discharge, we believe that using detection data to establish a lag time between turbidity measure and turbid water mass arrival in the plume is reasonable (Berggren \& Filardo 1993). Lagged daily turbidity measurements were averaged over the period between plume entry and plume departure for each group.

\section{ANALYSIS}

\section{Plume survival and occupancy}

Estimates of yearling Chinook salmon Oncorhynchus tshawytscha survival in the plume were obtained using the data and analytical methods described in Porter et al. (2012b). Briefly, a total of 4646 acoustic tagged smolts were released in the Columbia River basin from 2008 to 2011 (Table 1). Detection data from the array components extending from the Snake River to Lippy Point, British Columbia, Canada (Fig. 1), were used to estimate apparent survival for each treatment group between each detection site in each year using a special case of the CormackJolly-Seber (CJS) live-recapture modeling framework, implemented in the program MARK (Table 1; Lebreton et al. 1992, White \& Burnham 1999). Unique detection probabilities $(p)$ for each release group were estimated at each sub-array in the river; however, at the ocean sub-arrays, a common $p$ for the groups was used each year. Eight of the 19 fish detected migrating upriver in their release year were detected at the river mouth, but not at Willapa Bay. We did not remove them from the analysis because they affect plume survival estimates by only a fraction of a percent and have no effect on the final results. However, all upstream migration detections were scrubbed prior to analysis.

In 2010 and 2011, an additional sub-array was placed at Sand Island, seaward and adjacent to the Astoria sub-array (Fig. 1). Porter et al. (2012a) report 2010 and 2011 plume survival in 2 segments: Astoria and Sand Island and Sand Island to Willapa Bay. To permit inter-year comparisons, the methods in Porter et al. (2012a) were modified by setting survival to Sand Island at 1 so that mortality was estimated from Astoria to Willapa Bay. Plume survival estimates in 2008 and 2009 are as reported in Porter et al. (2012a). Median $\hat{c}$ goodness-of-fit tests, carried out in the program MARK, of the 2008, 2009, and 2011 specialcase CJS models used to estimate plume survival did not give evidence of extra-binomial variation (i.e. greater variability than would be expected under binomial sampling, which, if present, would result in underestimates of the variance of the CJS model parameters; Burnham \& Anderson 2002). We made corrections to the 2010 survival estimates because there was evidence of minor overdispersion $(\hat{c}=1.16$; Burnham \& Anderson 2002).

Plume occupancy included the period between plume entry and plume departure. Entry and departure dates were calculated as the median of final detection dates on the Astoria sub-array (plume entry; Fig. 1) and the median of final detection dates on the Willapa Bay sub-array (plume departure; Fig. 1). Plume entry and departure were calculated for each group in each year. Median absolute deviation of the plume entry time (i.e. the spread) was calculated for each group in each year.

\section{Modeling survival and plume residence time}

If smolt survival was mediated by travel time through the plume, time-scaled survival, calculated as $S_{\mathrm{TS}}=S_{\mathrm{P}}^{1 / T_{\mathrm{P}}}$, should be nearly constant and survival could be explained as an exponential decay process, which is time dependent. We fit an exponential decay model to the survival estimates using the nls function in R ( $R$ Development Core Team 2011):

$$
S_{\mathrm{P}}=\mathrm{e}^{-\mathrm{k} T_{\mathrm{P}}}
$$

where $S_{\mathrm{P}}$ is plume survival, $T_{\mathrm{P}}$ is median residence time, $\mathrm{k}$ is the mortality rate constant, and $e^{-\mathrm{k}}$ is the 
apparent daily survival rate. The assumptions of nonlinear regression-(1) correct function, (2) homoscedasticity, and (3) normally distributed error terms - were evaluated with a plot of the fitted regression curve, a plot of the model residuals against fitted values, and a quantile-quantile (QQ) plot, respectively (Kutner et al. 2005, Ritz \& Streibig 2008). We obtained an estimate of the bias in $\mathrm{k}$ through bootstrap resampling $(\mathrm{n}=10000$; Kutner et al. 2005). We calculated the confidence intervals for the exponential decay model by log transforming the confidence intervals of the linear form of the exponential model $\left(\log S_{\mathrm{P}}=-\mathrm{k} T_{\mathrm{P}}\right)$.

We plotted logit-transformed survival estimates and residuals from the exponential decay model against the variables representing productivity (BST, CU2, CU4) and gas supersaturation (PDG) to evaluate the potential role of biological productivity and exposure to supersaturated river water on plume survival (Kutner et al. 2005). We also calculated the coefficients of determination $\left(R^{2}\right)$ between logit-transformed survival estimates and each of the variables representing productivity and exposure.

We used linear regression models and information theoretic approaches to evaluate the environmental factors potentially governing plume residence time (Burnham \& Anderson 2002, Johnson \& Omland 2004, Kutner et al. 2005). Our general model of plume residence time, which included 3 covariates and 1 interaction term, was:

$$
T_{\mathrm{P}} \sim \mathrm{SST}+\mathrm{UP}+\mathrm{DIS}+\mathrm{UP}: \mathrm{DIS}
$$

We used corrected Akaike information coefficients (AICc), Akaike weights $\left(w_{i}\right)$, and evidence ratios, implemented in R with the package MuMIn, to evaluate and rank the general model and 8 sub-models in our candidate set (Burnham \& Anderson 2002, Barto 2012). We used diagnostic plots of the residuals to assess whether the assumptions of linear regression were met for the top ranked model. Additionally, the residuals of the top model were plotted against variables omitted from the general model to verify that they did not add descriptive or predictive power (Kutner et al. 2005).

\section{Model evaluation with 2006 survival data}

Although lower river and plume survival were conflated in 2006 due to the lack of a sub-array at Astoria, we derived estimates of plume survival and residence time for 2006 using travel times and average survival between Bonneville Dam and Astoria from 2008 to 2011. The derived estimates are plotted against the exponential decay model output as an additional test of the model's adequacy. We estimated plume survival in 2006 by dividing the 2006 estimates of combined lower river/plume survival (Bonneville Dam to Willapa Bay) by the average lower river survival (Bonneville Dam to Astoria) in 2008 to 2011 (average $=0.85$ ). We used the range of lower river survival from 2008 to 2011 ( 0.71 to 0.99 ; Porter et al. 2012a) to estimate a 2006 maximum and minimum plume survival (Table 2). To estimate 2006 plume residence time, we first calculated the average proportion of time spent in the plume relative to the combined time in the lower river and plume for 2008 to 2011 (proportion $=0.64$ ). This proportion was multiplied by the 2006 combined lower river/plume residence time to yield estimates of 2006 plume residence time for each group (Table 2).

\section{ASSUMPTIONS AND TESTS}

The use of acoustic telemetry and CJS modeling to estimate survival requires a number of assumptions, including that (1) there are no tag effects, (2) tags are not lost, (3) the size range of fish used in the study is representative of the source populations and there is no effect of fork length on survival, (4) every tagged smolt has the same probability of being detected, (5) sampling is instantaneous, (6) the offshore extent of the marine sub-arrays is sufficient to bound the early marine migratory path, and (7) smolts departing the Columbia River migrate north. Here, we summarize the results of tests of these assumptions, which are also available in uncondensed form in Porter et al. (2009b, 2010, 2011, 2012a,b).

Captive tag effects and tagging-induced mortality studies were conducted in 2008 to 2011 to study the

Table 2. Oncorhynchus tshawytscha. Estimates of combined lower river/ plume survival and residence time and derived plume residence time and survival for acoustic-tagged Chinook smolts released in 2006 in the Snake River (SR_06) and Columbia (CR_06), or Snake River-sourced smolts that were transported and released below Bonneville Dam (ST_06)

\begin{tabular}{|cccccc|}
\hline Group & $\begin{array}{c}\text { No. } \\
\text { of } \\
\text { fish }\end{array}$ & $\begin{array}{c}\text { Combined } \\
\text { residence } \\
\text { time (d) }\end{array}$ & $\begin{array}{c}\text { Combined } \\
\text { survival } \\
\text { (SE) }\end{array}$ & $\begin{array}{c}\text { Derived plume } \\
\text { residence } \\
\text { time (d) }\end{array}$ & $\begin{array}{c}\text { Derived plume } \\
\text { survival } \\
\text { (range) }\end{array}$ \\
\hline SR_06 & 380 & 3.73 & $0.71(0.19)$ & 2.40 & $0.83(0.72-1.00)$ \\
ST_06 & 203 & 8.10 & $0.56(0.14)$ & 5.22 & $0.66(0.56-0.79)$ \\
CR_06 & 398 & 5.76 & $0.81(0.20)$ & 3.71 & $0.95(0.82-1.00)$ \\
\hline
\end{tabular}


survival, tag retention, and growth of Oncorhynchus tshawytscha smolts implanted with V7-2L dummy acoustic tags (DATs) relative to PIT-tagged controls (Porter et al. 2009b, 2010, 2011, 2012b). Small initial effects on growth rates of DAT-tagged smolts were observed. Tag retention was high; no V7-2L DATs were shed in 2008. In 2009, 9 (of 210) DATs were shed, 2 (of 188) were shed in 2010, and 1 (of 87) was shed in 2011. In all years, there were no significant differences in survival or mean fork length between the DAT-tagged and control fish at the conclusion of the studies. To ensure that tag burdens were unlikely to impact survival, we restricted tagging in all years to smolts with a minimum fork length (FL) of $130 \mathrm{~mm}$ (one $129 \mathrm{~mm}$ smolt was tagged in 2008), which is below the ratio of tag size to smolt size where tag burdens have been found to be significant (Lacroix et al. 2004). Ninety-two percent of tagged smolts also had tag burdens $<6.7 \%$ of their body weight, the level at which Brown et al. (2006) found that tag burdens may begin to exert an effect on survival.

The $130 \mathrm{~mm}$ FL minimum generally restricted tagging to the upper 68 to $88 \%$ of the study populations. In 2008, Snake River smolts collected at the Dworshak hatchery were small, and tagged smolts represented only the upper $10 \%$ of the population of smolts reared at Dworshak National Fish Hatchery. However, the fork length spectrum represented $76 \%$ of the population of hatchery Chinook sampled at the Lower Granite Dam smolt monitoring facility in 2008. Fork length ranges and the proportions of study populations they represent are reported in Table 1. Smolt size has been linked to adult returns and may influence early marine survival (Tomaro et al. 2012). We recorded fork lengths at tagging and compared the fork length frequency distributions of the released fish to those that survived to Willapa Bay. If larger size conferred a survival advantage to Willapa Bay, we would expect the size distribution of survivors to be right-skewed relative to the overall release group. However, the distributions were virtually identical, indicating that there was no size-selective effect (Fig. 2).

Violations of the assumption that every tagged smolt has the same probability of detection should be evident in a lack of fit of standard CJS models to the detection data (the standard CJS model has unique parameters for the probability of survival to, and detection at, each sub-array and thus contains more parameters than the special-case model used to estimate survival in this analysis). There was no evidence in median $\hat{c}$ tests, conducted in the program MARK, of a lack of fit to the 2008 through 2011 data, indicating that this assumption was not violated (Porter et al.

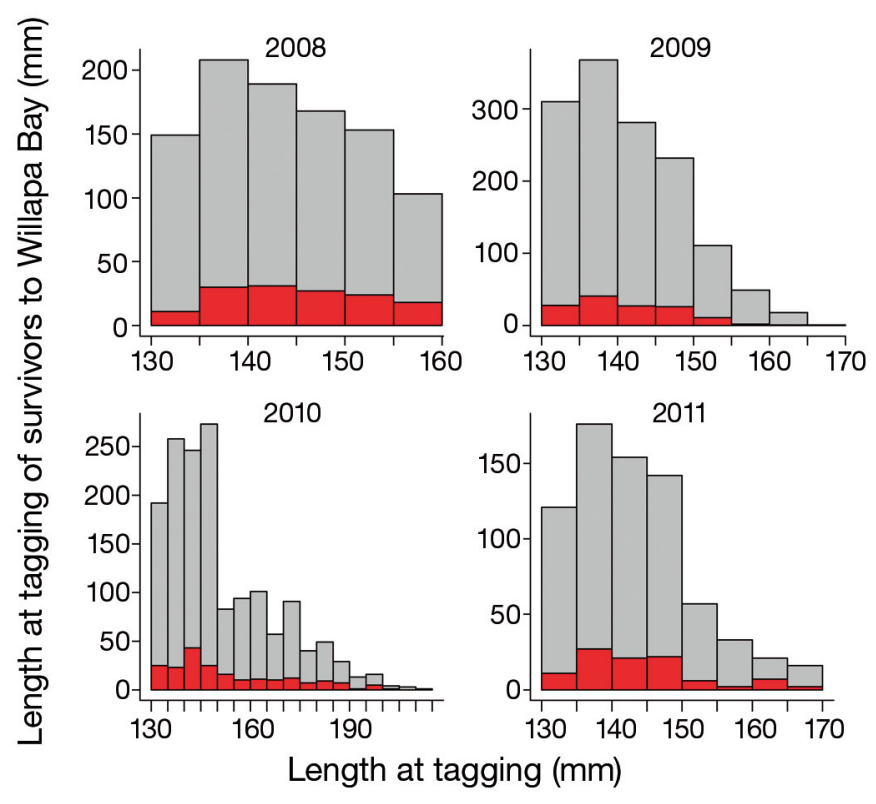

Fig. 2. Oncorhynchus tshawytscha. Frequency distributions of the fork lengths of all tagged smolts (gray) and smolts detected at the Willapa Bay sub-array (red). Fork length was measured at the time of tagging. The similarity in the distributions indicates that there was no size-selective effect on survival to the Willapa Bay sub-array

2012a). Instantaneous sampling is the assumption of demographic closure at each sampling period, and, in practice, sampling periods in mark-recapture studies are short, rather than truly instantaneous. From 2008 to 2011, individual fish crossed the arrays within hours of first detection, and the sampling periods at the lower river and Willapa Bay sub-arrays (i.e. the periods between arrival of the first and last smolts in each group) only lasted for several days.

Extensive ocean sampling of juvenile salmon off Oregon and Washington has shown that juveniles are generally confined to the shelf region (Bi et al. 2007, Peterson et al. 2010). From 2008 to 2010, the sub-array at Willapa Bay extended offshore to the $200 \mathrm{~m}$ isobath, but was extended to the $500 \mathrm{~m}$ isobath in 2011 because smolts continued to be detected on the outermost receivers. In 2011, 9 smolts were detected on the extended receivers, indicating a small number of smolts may have passed outside the detection range of the Willapa Bay sub-array in 2008 to 2010. No smolts were detected on the outermost receivers in 2011, although the receivers were lost, likely to fishing activity, sometime during the 2011 migration season (Porter et al. 2012a). Missed detections could result in a downward bias in plume survival estimates, although CJS modeling alleviates this problem by using subsequent detections at the 
Lippy Point sub-array (which are heavily skewed towards the inner shelf) to adjust estimates of survival at Willapa Bay (Porter et al. 2012a).

Miller et al. (1983) demonstrated with north- and south-opening nets that juvenile salmon swim north after entering the ocean. In 2009 and 2011, a subarray was deployed at Cascade Head, Oregon, to verify the assumption that fish swim north at ocean entry (Fig. 1). The small number of detections at Cascade Head (3 fish in 2009 [number released $=1370$ ] and 6 in 2011 [number released $=725$ ]), suggest the conclusion by Miller et al. (1983) was correct. One of the 6 tagged fish detected at Cascade Head in 2011 was subsequently detected at both Willapa Bay and Lippy Point, further supporting this conclusion. Fish detections at Cascade Head were included in the Willapa sub-array detections to reflect their survival in the plume. We have excluded a group of transport fish released in early-April 2009. This group was released much earlier in the season than the remaining groups (Porter et al. 2009b) and may have entered the plume before predators became abundant (see 'Discussion').

\section{RESULTS}

Initial exploration with pairwise plots of the variables and their Pearson correlation coefficients revealed that several variables potentially related to survival, but without clear mechanistic relationships, were also associated with plume residence time. Thus, we divided the variables into 2 categories, those that might affect survival of Oncorhynchus tshawytscha indirectly by influencing plume residence time (upwelling at ocean entry, discharge, SST), and those that might directly affect survival by way of feeding opportunities (timing of the biological spring transition, 2 and $4 \mathrm{wk}$ cumulative upwelling prior to ocean entry) or reduced physiological fitness (dissolved gas levels). We excluded turbidity (measured at Bonneville Dam) due to its high correlation with discharge $($ Pearson correlation coefficient $=$ $0.95)$ and the distance $(146 \mathrm{~km})$ between the dam and the plume. Similarly, we did not consider spill at Bonneville Dam (the final dam in the river) because it is correlated with discharge and does not reflect additional downstream freshwater inputs to the plume.

Plume survival varied widely, but the daily plume survival rate $\left(S_{\mathrm{TS}}\right)$ was similar among groups (Fig. 3 ). The estimated mortality rate constant, $\mathrm{k}$, across the groups was $0.12 \mathrm{~d}^{-1}$. There was no evidence of violation of homoscedasticity in the exponential decay

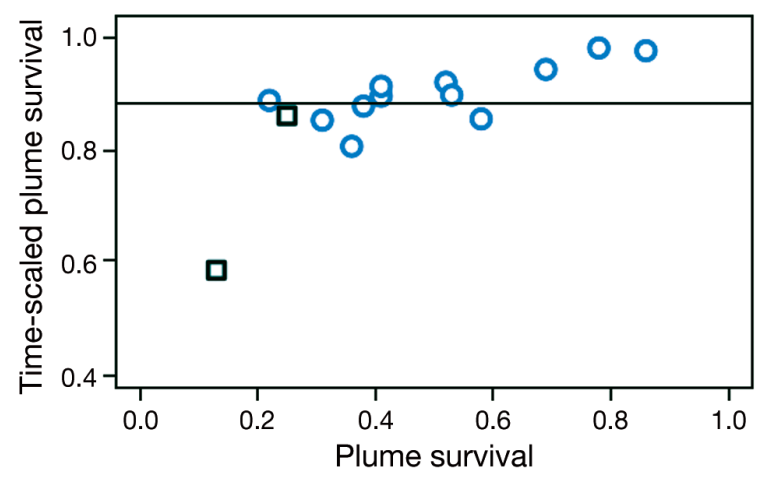

Fig. 3. Oncorhynchus tshawytscha. Comparison of plume survival with daily survival rates (open circles). Although plume survival varied widely, the daily survival rate was similar among groups, illustrating the potential effect of residence time on plume survival. The outlier with both low survival and low time-scaled survival was 1 of 2 groups (open squares), exposed to high total dissolved gas concentrations (TDG $>120 \%$ ) in the lower river. The gray line is the model estimated daily survival rate

model, the error terms appeared normal, and the bias of the estimate of $\mathrm{k}$ was low (bias $=-0.003$ ). However, the plot of the fitted regression curve suggests that the model performed well in predicting survival of the groups that migrate in-river, but did not perform as well for groups transported and released below Bonneville Dam (Fig. 4). In-river migrants entered the plume in a more continuous fashion, whereas transported fish entered in brief pulses; the median absolute deviation from the median plume entry date of transported juveniles was $<1 \mathrm{~d}$ (mean $=0.56 \mathrm{~d})$, but ranged from 1 to $7 \mathrm{~d}$ (mean $=3.39 \mathrm{~d}$ ) for the in-river migrants (Fig. 4). The plume residence time of all groups was brief, averaging $7.29 \mathrm{~d}$ (Table 3 ).

The high variability in survival of the 2008 to 2011 transport groups limits further inference regarding these groups, and the remaining results pertain only to the in-river groups (transport group data are plotted in Fig. 5 for reference). Plots of logit-transformed survival estimates against timing of the biological spring transition relative to plume entry and 2 and 4 wk cumulative upwelling prior to plume entry did not provide evidence of any influence on plume survival (Fig. 5). Additionally, there were no strong patterns in the plots of the model residuals against these variables to suggest that incorporating them would improve the model (Fig. 5).

Survival appears lower at higher (>120\%) levels of dissolved gas supersaturation, which may be evidence of a threshold level of exposure at which gas supersaturation levels experienced in the lower river noticeably affect subsequent plume survival, al- 

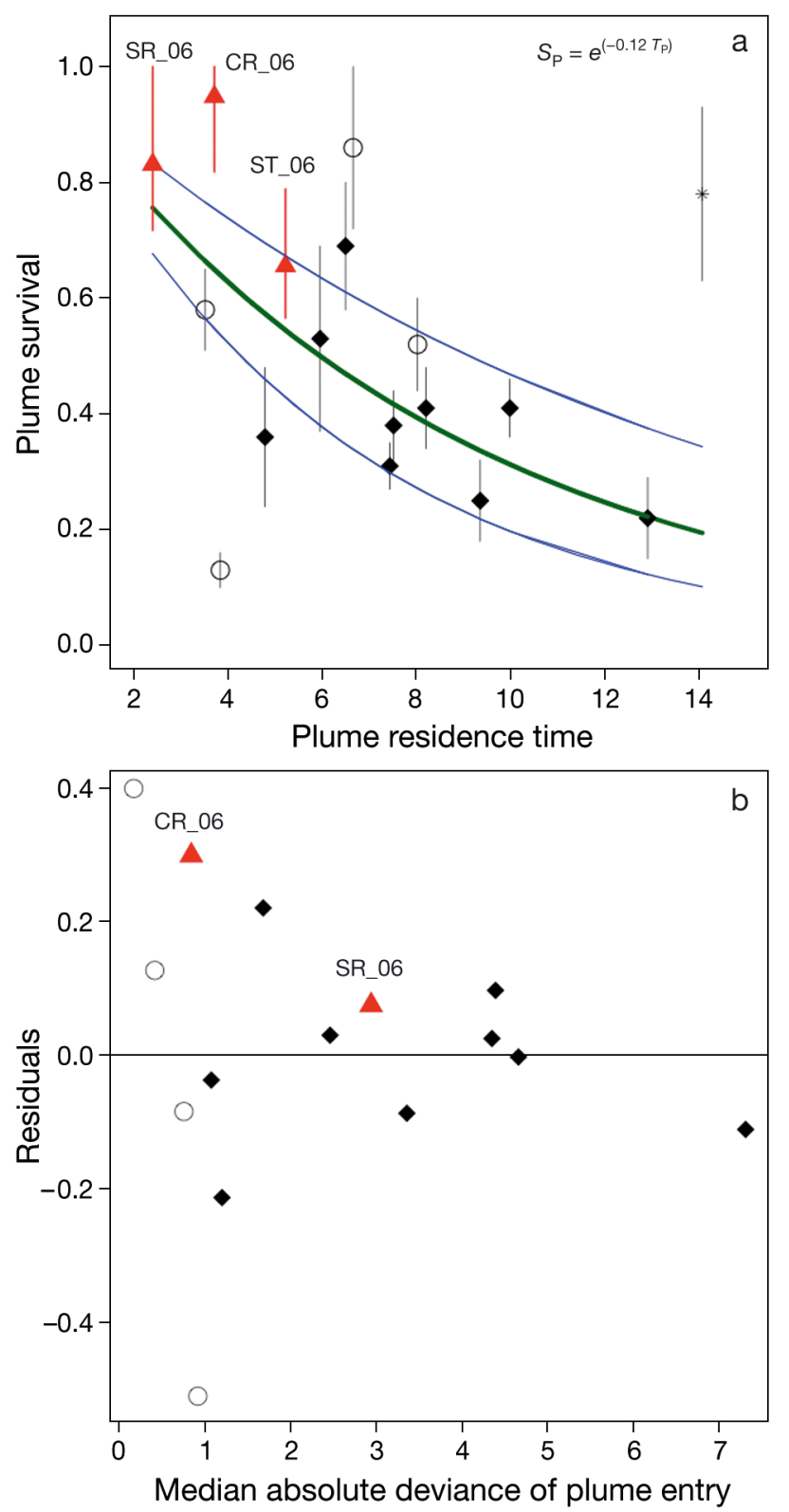

Fig. 4. Oncorhynchus tshawytscha. (a) Comparison of plume survival with plume residence time, showing the regression curve (thick green line) and 95\% confidence intervals (thin blue lines). The model clearly fits the in-river migrant groups (black diamonds, $\pm 95 \% \mathrm{CI}$ ) better than transported groups (open circles, $\pm 95 \%$ CI). Derived estimates of 2006 plume survival and residence time (red triangles; vertical red lines show maximum and minimum estimates) also fit the pattern of a simple exponential decline in survival with residence time. The 2009 early-release transport group excluded in calculations is also shown (star, $\pm 95 \%$ CI). (b) Residuals from the regression relationship exhibit greater variance when the spread in plume entry times is low (measured by median absolute deviation), as is also the case for all of the transport groups (open circles) in this study. Median absolute deviation at the Bonneville dam sub-array is shown for 2006 (triangles); there are no data for the 2006 transport group as they were released in the vicinity of Bonneville sub-array though the evidence for this is weak (Fig. 5). The density of data points at high levels of dissolved gas is less than at lower levels, and the apparent relationship is determined by low survival in a single year, 2011, when dissolved gas levels below Bonneville Dam exceeded the $120 \%$ limit established under Oregon and Washington water quality law (USACOE 2011). We did not see evidence in the residual plot that this exposure should have been incorporated into the survival model (but see 'Discussion').

In 2006, smolt travel time between Bonneville Dam and Willapa Bay was short and survival was high, as are the derived estimates of plume residence time and survival (Table 2; Porter et al. 2012a). Additionally, the model performs better in predicting survival of the SR_06 group, which entered the lower river in a more continuous manner than the CR_06 group (Fig. 4). Refitting the exponential decay model to include the 2006 data only changes the decay constant slightly, from 0.12 to 0.11 .

Among the 9 candidate models for predicting plume residence time, the model containing only SST outperformed all others, as measured by AICc distance and model weights (weight $=92 \%$; Table 4 and Fig. 6). Diagnostic plots of the SST model did not show evidence of heteroscedasticity or non-normal error terms, and there were no patterns in the plots of the SST-model residuals against the omitted variables, upwelling and discharge, to indicate that that these variables should be included.

\section{DISCUSSION}

The Columbia River plume was once posited to benefit juvenile salmon by providing food and refuge while transporting them to safer environs (Casillas 1999). However, research has shown that juvenile salmon do not take advantage of feeding opportunities presented by the plume (DeRobertis et al. 2005, Morgan et al. 2005) and that the plume is rich in salmon predators (Collis et al. 2002, Anderson et al. 2004, Lyons et al. 2005 Emmett et al. 2006). More recently, acoustic telemetry studies have shown that yearling Chinook Oncorhynchus tshawytscha survival in the plume is low in relation to river, estuary, and coastal ocean habitats (Porter et al. 2010, 2012a). Thus, the telemetry data suggest that reducing plume residency may increase yearling Chinook salmon productivity by allowing the smolts to move into regions with higher survival, which runs contrary to initial thinking that the plume might be a refuge where longer residence could increase adult return rates. 
Table 3. Oncorhynchus tshawytscha. Plume residence time and environmental data summary. The ST_09ER group, shown for reference, was not included in the analysis. For explanation of group designations, see Table 1

\begin{tabular}{|c|c|c|c|c|c|c|c|c|}
\hline Group & $\begin{array}{l}\text { Plume } \\
\text { residence } \\
\text { time (d) }\end{array}$ & $\begin{array}{l}\text { Days since } \\
\text { biological } \\
\text { spring } \\
\text { transition }\end{array}$ & $\begin{array}{l}\text { Cum } \\
\text { upy } \\
\left(\mathrm{m}^{3} \mathrm{~s}^{-1}\right. \\
2 \mathrm{wk}\end{array}$ & $\begin{array}{l}\text { ative } \\
\text { ling } \\
00 \mathrm{~m}^{-1} \text { ) } \\
4 \mathrm{wk}\end{array}$ & $\begin{array}{l}\text { Percent } \\
\text { dissolved } \\
\text { gas }\end{array}$ & $\begin{array}{c}\text { Sea- } \\
\text { surface } \\
\text { temperature } \\
\left(\mathrm{C}^{\circ}\right)\end{array}$ & $\begin{array}{c}\text { Upwelling } \\
\left(\mathrm{m}^{3} \mathrm{~s}^{-1} 100 \mathrm{~m}^{-1}\right)\end{array}$ & $\begin{array}{c}\text { Discharge } \\
\left(\mathrm{m}^{3} \mathrm{~s}^{-1}\right)\end{array}$ \\
\hline SR_08 & 8.21 & 84 & 243 & 233 & 118.1 & 11.46 & 8.22 & 13756.4 \\
\hline ST_08 & 8.03 & 82 & 32 & 48 & 118.0 & 11.42 & 12.44 & 13866.7 \\
\hline CR_08 & 7.52 & 85 & 267 & 332 & 118.3 & 11.44 & 10.44 & 13496.3 \\
\hline SR_09 & 5.96 & 84 & 286 & -550 & 117.7 & 13.16 & 9.71 & 11194.7 \\
\hline ST_09 & 6.66 & 85 & 383 & -527 & 117.9 & 13.49 & 3.57 & 11271.6 \\
\hline ST_09ER & 14.08 & 51 & 470 & 445 & 113.3 & 9.95 & -27.87 & 9551.8 \\
\hline CR_09 & 4.79 & 87 & 323 & -424 & 118.3 & 13.82 & 2.80 & 11243.3 \\
\hline SR_10 & 6.50 & -23 & 25 & 261 & 113.3 & 13.43 & 18.50 & 12461.1 \\
\hline $\mathrm{ST}_{-} 10$ & 3.52 & -31 & 128 & 297 & 113.4 & 11.02 & 14.00 & 8814.2 \\
\hline CR_10 & 9.99 & -44 & 612 & 324 & 113.1 & 11.00 & -34.55 & 8074.7 \\
\hline SR_11 & 9.36 & 62 & 57 & 16 & 124.6 & 12.33 & 2.00 & 16717.2 \\
\hline ST_11 & 3.84 & 61 & -52 & -98 & 123.7 & 11.49 & -7.20 & 16419.6 \\
\hline UC_11 & 7.44 & 58 & 2 & -71 & 116.8 & 11.47 & 1.75 & 14940.6 \\
\hline MC_11 & 12.92 & 48 & 35 & -86 & 113.4 & 10.73 & 6.79 & 13781.0 \\
\hline
\end{tabular}

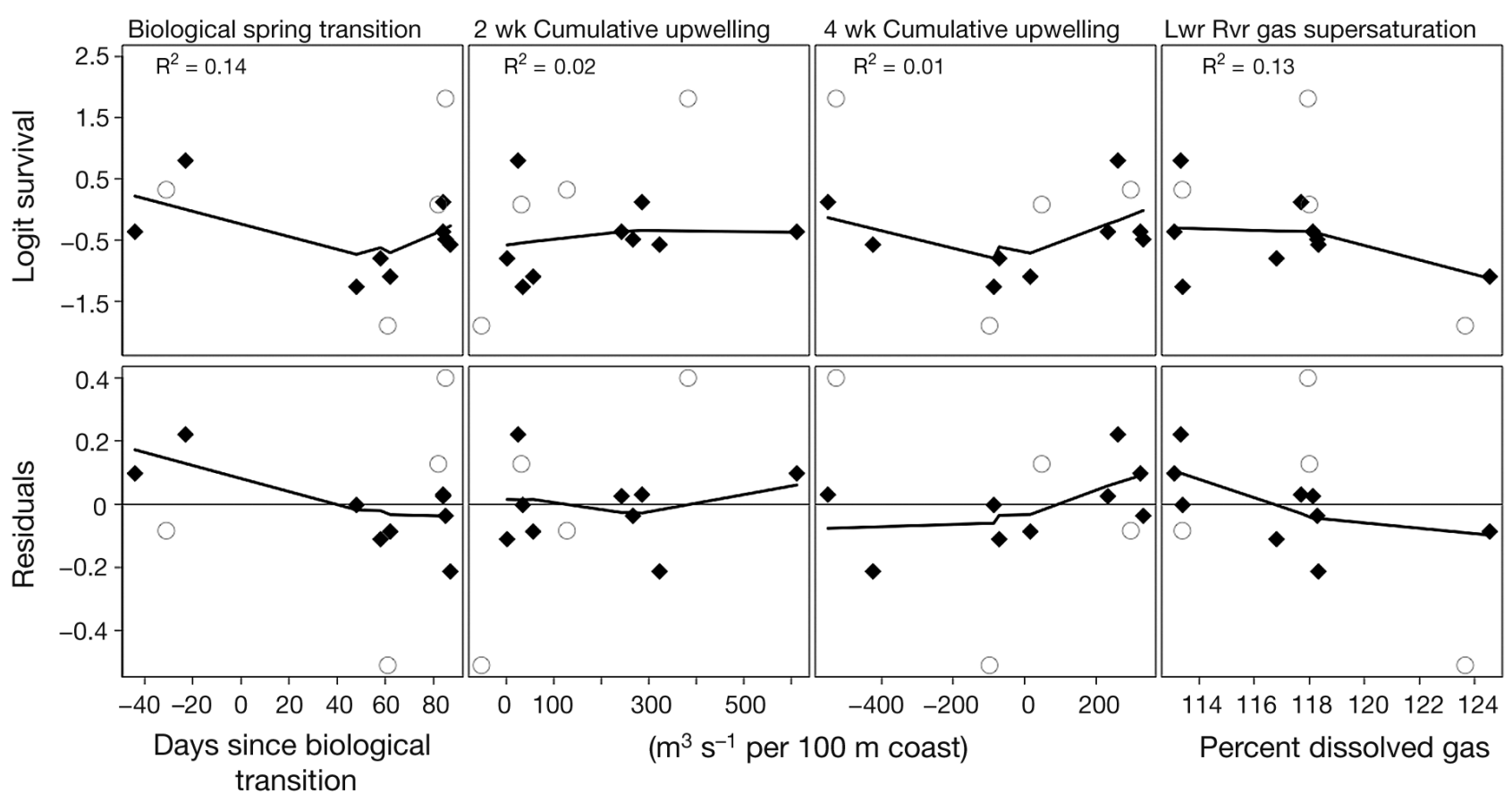

Fig. 5. Oncorhynchus tshawytscha. Upper panels: logit-transformed survival compared with measures of coastal productivity and lower river total dissolved gas levels; no clear relationships are evident. Lower panels: plots of residuals from the exponential decay model do not reveal patterns, indicating that the model would be improved by including biological productivity or exposure to gas supersaturated water. Coefficients of determination $\left(R^{2}\right)$ and Friedman's supersmoother lines $(R$ Development Core Team 2011) are fitted to the in-river groups (diamonds). Transport group data (open circles) are shown for reference

Although plume survival estimates in this study ranged from 0.13 to 0.86 , they stabilized when scaled by residence time (Fig. 3). If mortality rates in the plume are consistent at comparable periods in the migratory season (groups used in this analysis were released at similar periods each year), then plume survival could be governed by residence time. Consistent with this idea, we find that a simple exponential decay model largely describes plume survival, although the model performs best when analysis is restricted to groups of yearling Chinook whose individuals enter the plume over a longer time period. 
Table 4. Oncorhynchus tshawytscha. AIC-based ranking of 9 candidate models of plume residence time containing hypothesized combinations of 3 predictor variables, sea-surface temperature (SST), upwelling (UP), and river discharge (DIS). Evidence is a measure of how many times less likely the model is the best model relative to the top ranked model. AIC $\mathrm{C}_{\mathrm{c}}$ corrected

Akaike's information criterion

\begin{tabular}{|c|c|c|c|c|c|c|c|c|c|}
\hline Model & Intercept & SST & $\begin{array}{l}\text { Parameters } \\
\text { UP }\end{array}$ & DIS & DIS:UP & $\mathrm{AIC}_{\mathrm{c}}$ & $\Delta \mathrm{AIC}_{\mathrm{c}}$ & $\begin{array}{l}\text { Model } \\
\text { weight }\end{array}$ & Evidence \\
\hline $\mathrm{SST}$ & 29.06 & -1.74 & - & - & - & 41.77 & 0 & 0.92 & 1.0 \\
\hline $\mathrm{SST}+\mathrm{DIS}$ & 27.83 & -1.72 & - & 0.000078 & - & 48.81 & 7.034 & 0.027 & 33.7 \\
\hline $\mathrm{SST}+\mathrm{UP}$ & 29.12 & -1.74 & 0.00094 & - & - & 48.97 & 7.19 & 0.025 & 36.6 \\
\hline UP & 8.228 & - & -0.053 & - & - & 50.25 & 8.47 & 0.013 & 69.2 \\
\hline DIS & 5.966 & - & - & 0.00016 & - & 51.0092 & 9.24 & 0.0091 & 101.3 \\
\hline UP + DIS & 1.838 & - & -0.10 & 0.00051 & - & 55.37 & 13.59 & 0.0010 & 894.6 \\
\hline $\mathrm{SST}+\mathrm{UP}+\mathrm{DIS}$ & 25.89 & -1.62 & -0.016 & 0.00014 & - & 60.69 & 18.92 & 0.000071 & 12834.7 \\
\hline $\mathrm{UP} \times \mathrm{DIS}$ & -2.11 & - & -0.66 & 0.00069 & 0.000058 & 65.056 & 23.28 & 0.0000081 & 113745.3 \\
\hline $\mathrm{SST}+\mathrm{UP} \times \mathrm{DIS}$ & 22.15 & -1.45 & -0.20 & 0.00023 & 0.000018 & 84.37 & 42.59 & 0.0000000052 & 1778441824.7 \\
\hline
\end{tabular}
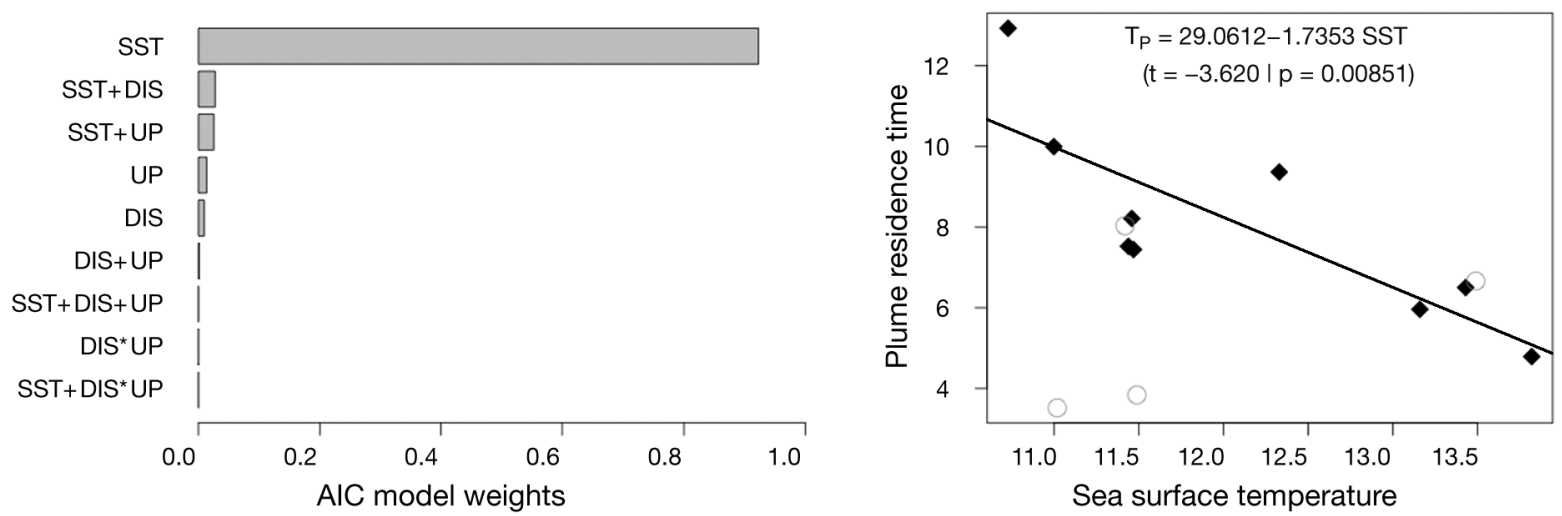

Fig. 6. Oncorhynchus tshawytscha. (a) Model ranking for the influence of environmental variables on plume survival; the seasurface temperature (SST) model receives the greatest proportion of model weight. (b) The inverse relationship between SST and plume residence time suggests that most of the predictive power occurs because smolts do not remain in the plume for long when coastal temperatures are high, increasing survival to Willapa Bay. Diamonds: in-river migrants; open circles: transport groups. For explanation of model abbreviations, see Table 4

This scenario is also consistent with the hypothesis that predation is a key driver of survival in the plume region and provides a plausible bridge between survival and environmental variables, such as river discharge and SST, that have been hypothesized to influence early marine survival, but lack a clear link. The derived estimates of 2006 plume residence time and survival provide additional qualitative support to the idea that plume survival is negatively related to travel time.

The variability in plume survival of the 2008 to 2011 transport groups relative to the fitted regression line suggests that there may be substantial variation in mortality events around the average daily rate that we propose. Over short periods of time $(<1 \mathrm{~d})$, pulses of smolts travelling between the Astoria and Willapa Bay sub-arrays may or may not encounter significant numbers of foraging predators, resulting in groups experiencing either very high survival if they pass through the plume without encountering predator aggregations, or very low survival if they encounter substantial number of predator groups. In this scenario, survival of such groups would appear to be more variable than groups whose plume entry times are more dispersed over time, even though the same underlying mortality rate process may apply.

We believe that plume residence times (average: $7.29 \mathrm{~d}$ ) were too short for starvation to have had an effect and that predation was the most likely cause of plume mortality. The density of piscivorous hake Merluccius productus in the plume generally increases in May and peaks in June and July (Agostini et al. 2006, Emmett et al. 2006), and, similarly, the contribution of salmonids to the diet of Caspian terns Sterna caspia and double-crested coromorants Phalacrocorax auritus that nest near the plume peaks in May (Collis et al. 
2002, Lyons et al. 2005). Predation by these piscivorous birds and fish may exert significant top-down control on plume survival (Collis et al. 2002, Anderson et al. 2004, Lyons et al. 2005, Emmett et al. 2006, Emmett \& Sampson 2007), although this has not been conclusively demonstrated. We suspect that the high survival of the early-April 2009 release group, despite a long plume residence time, may be related to the May and June peaks in predation by piscivorous birds and fish (Collis et al. 2002, Anderson et al. 2004, Lyons et al. 2005, Emmett et al. 2006). This is consistent with an effect of emigration timing on early-marine survival (Muir et al. 2006) and the idea that the mortality rate may vary through the migration season. Unfortunately, with only a single data point and no predator data, any inference is severely restricted.

Although the temporal match, or mismatch, between juvenile salmon entering the plume and the timing of spring increases in marine productivity and advection of lipid-rich copepods into marine waters off Oregon and Washington (the biological spring transition) may affect feeding opportunities, plume survival of the groups used in this study does not appear to be related to biological productivity measures. However, biological productivity and the availability of higher quality prey is still potentially relevant to survival at larger temporal scales as it may affect whether juveniles obtain sufficient energy reserves to survive their first winter at sea (Beamish \& Mahnken 2001, Tomaro et al. 2012).

The practice of spilling water over Columbia River dam faces (rather than through turbines) to reduce the physical and physiological stress on juvenile salmon can supersaturate the river below the dam with atmospheric gases, potentially leading to gas bubble trauma and, when exposure is non-lethal, reducing fitness (Bouck 1980, Mesa \& Warren 1997). During the 2008 to 2011 period, percent dissolved gas levels recorded at the Camas/Washougal monitoring station below Bonneville Dam ranged from a relatively benign $113 \%$ to a potentially harmful $125 \%$ during flood conditions in 2011 (Bouck 1980, USACOE 2011). Although we found little evidence that dissolved gas exposure explains the variation in plume survival among the groups used in this analysis, an intra-year analysis of the smolts released in 2011 after total dissolved gas levels exceeded state legal limits at the Bonneville Dam release site suggests they may have experienced lower daily survival rates in the river and plume compared with their unexposed counterparts (I. G. Brosnan et al. unpubl. data).

Plume residence time may be affected by water temperature, which has been related to migration timing and speed (Brett et al. 1958, Sykes \& Shrimpton 2010, Martin et al. 2012), and river discharge and wind-driven surface currents (reflected in the coastal upwelling index) that may affect travel time by changing the area and depth of the plume and adjusting its orientation between a northern, onshore configuration, or a southwestern, offshore configuration (Hickey et al. 2005, Burla et al. 2010b). The best model of plume residence, by a significant margin, included only SST. Models that included river discharge, which can be influenced by management action, or coastal upwelling, have little weight. This is consistent with Burla et al. (2010a), who found that the physical dynamics of the plume at the time of ocean entry do not affect adult returns of yearling Chinook (although it may affect steelhead returns). If our results are widely applicable, they also suggest that plume survival may not be amenable to improvement via management of the hydropower system, although it is conceivable that hatchery and fish transport releases could be timed to minimize plume residence. However, this would require detailed forecasts of conditions in the early marine environment that are not presently available.

Advances in marine acoustic telemetry have played an important role in addressing scientific questions and conservation problems in the Columbia River basin. Rechisky et al. (2009, 2012, 2013, 2014 , this volume) and Welch et al. $(2009,2011)$ have measured directly the survival of juvenile salmon in key marine habitats and conducted direct experimental tests of survival hypotheses related to dam passage and the downriver transport of juvenile Chinook. Additional releases of telemetered yearling Chinook would provide greater clarity regarding the drivers of plume residence time and could better address the question of plume survival in relation to predator abundance and distribution. Nonetheless, we have shown here that a simple exponential decay model adequately described the survival of juvenile yearling Chinook in the Columbia River plume, and that the ability of resource managers to affect plume survival of yearling Chinook by altering residence time may be limited. If correct, this poses a potential problem, as survival in the plume is low relative to other habitats (Porter et al. 2010, 2012a). Survival might potentially be improved by the successful development of marine environmental forecasts to aid in release timing, and the telemetry data used in this analysis can be extended to a value-of-information analysis to determine what the maximum financial outlay should be for such forecasts (Raiffa \& Schlaifer 1961, Williams et al. 2011). 
Acknowledgements. We thank Paul Callow, Melinda Jacobs Scott, Paul Winchell, and the vessel captains and crews who ensured that fish swam with tags and that there were receiver arrays in place to detect them. Biological spring transition data are courtesy of Dr. William T. Peterson via the Columbia River DART website. The US Dept. of Energy, Bonneville Power Administration provided funding for research under Project No. 2003-114-00. I.G.B. was supported by the US Department of Defense through the National Defense Science \& Engineering Graduate Fellowship Program.

\section{LITERATURE CITED}

Agostini VN, Francis RC, Hollowed AB, Pierce SD, Wilson C, Hendrix AN (2006) The relationship between Pacific hake (Merluccius productus) distribution and poleward subsurface flow in the California Current System. Can J Fish Aquat Sci 63:2648-2659

Anderson CD, Roby DD, Collis K (2004) Foraging patterns of male and female double-crested cormorants nesting in the Columbia River estuary. Can J Zool 82:541-554

Barto K (2012) MuMIn: multi-model inference. R package, Version 1.7.7. Available at: http://CRAN.R-project.org/ package=MuMIn

> Beamish RJ, Mahnken C (2001) A critical size and period hypothesis to explain natural regulation of salmon abundance and the linkage to climate and climate change. Prog Oceanogr 49:423-437

> Berggren TJ, Filardo MJ (1993) An analysis of variables influencing the migration of juvenile salmonids in the Columbia River Basin. N Am J Fish Manag 13:48-63

Bi H, Ruppel RE, Peterson WT (2007) Modeling the pelagic habitat of salmon off the Pacific Northwest (USA) coast using logistic regression. Mar Ecol Prog Ser 336:249-265

$>$ Bouck GR (1980) Etiology of gas bubble disease. Trans Am Fish Soc 109:703-707

Brett JR, Hollands M, Alderdice DF (1958) The effect of temperature on the cruising speed of young sockeye and coho salmon. J Fish Res Board Can 15:587-605

Brodeur RD, Francis RC, Pearcy WG (1992) Food consumption by juvenile coho (Oncorhynchus kisutch) and Chinook salmon (O. tshawytscha) on the continental shelf off Washington and Oregon. Can J Fish Aquat Sci 49: 1670-1685

Brodeur RD, Myers KW, Helle JH (2003) Research conducted by the United States on the early ocean life history of Pacific salmon. North Pac Anadromous Fish Comm Bull 3:89-131

> Brown RS, Geist DR, Deters KA, Grassell A (2006) Effects of surgically implanted acoustic transmitters $>2 \%$ of body mass on the swimming performance, survival and growth of juvenile sockeye and Chinook salmon. J Fish Biol 69:1626-1638

> Budy P, Thiede GP, Bouwes N, Petrosky CE, Schaller H (2002) Evidence linking delayed mortality of Snake River salmon to their earlier hydrosystem experience. N Am J Fish Manag 22:35-51

Burke BJ, Peterson WT, Beckman BR, Morgan C, Daly EA, Litz M (2013) Multivariate models of adult Pacific salmon returns. PLoS ONE 8:e54134

Burla M, Baptista AM, Casillas E, Williams JG, Marsh DM (2010a) The influence of the Columbia River plume on the survival of steelhead (Oncorhynchus mykiss) and
Chinook salmon (Oncorhynchus tshawytscha): a numerical exploration. Can J Fish Aquat Sci 67:1671-1684

Burla M, Baptista AM, Zhang Y, Frolov S (2010b) Seasonal and interannual variability of the Columbia River plume: a perspective enabled by multiyear simulation databases. J Geophys Res 115(C2):C00B16, doi:10.1029/ 2008JC004964

Burnham KP, Anderson DR (2002) Model selection and multimodel inference: a practical information-theoretic approach. Springer, New York, NY

Casillas E (1999) Role of the Columbia River estuary and plume in salmon productivity. In: Bisbal G (ed) Proceedings of the symposium on ocean conditions and the management of Columbia River salmon. Available at: http: //sbdashboard.nwcouncil.org/library/ocean/Default.htm (accessed 14 May 2013)

$>$ Cole J (2000) Coastal sea surface temperature and coho salmon production off the north-west United States. Fish Oceanogr 9:1-16

> Collis K, Roby DD, Craig DP, Adamany S, Adkins JY, Lyons DE (2002) Colony size and diet composition of piscivorous waterbirds on the lower Columbia River: implications for losses of juvenile salmonids to avian predation. Trans Am Fish Soc 131:537-550

Coronado C, Hilborn R (1998) Spatial and temporal factors affecting survival in coho and fall Chinook salmon in the Pacific Northwest. Bull Mar Sci 62:409-425

> DeRobertis A, Ryer CH, Veloza A, Brodeur RA (2003) Differential effects of turbidity on prey consumption of piscivorous and planktivorous fish. Can J Fish Aquat Sci 60: 1517-1525

> DeRobertis A, Morgan CA, Schabetsberger RA, Zabel RW and others (2005) Columbia River plume fronts. II. Distribution, abundance, and feeding ecology of juvenile salmon. Mar Ecol Prog Ser 299:33-44

Emmett RL, Sampson DB (2007) The relationships between predatory fish, forage fishes, and juvenile salmonid marine survival off the Columbia River: a simple trophic model analysis. Calif Coop Ocean Fish Invest Rep 48: 92-105

> Emmett RL, Krutzikowsky GK, Bentley PJ (2006) Abundance and distribution of pelagic piscivorous fishes in the Columbia River plume during spring/early summer 1998-2003: relationship to oceanographic conditions, forage fishes, and juvenile salmonids. Prog Oceanogr 68:1-26

> Gregory RS (1993) The effect of turbidity on the predator avoidance behaviour of juvenile Chinook salmon (Oncorhynchus tshawytscha). Can J Fish Aquat Sci 50:241-246

Gregory RS, Levings CD (1998) Turbidity reduces predation on migrating juvenile Pacific salmon. Trans Am Fish Soc 127:275-285

Hickey BM, Banas NS (2003) Oceanography of the U.S. Pacific Northwest coast and estuaries with application to coastal ecology. Estuaries 26:1010-1031

> Hickey BM, Geier SL, Kachel NB, MacFadyen A (2005) A bidirectional river plume: the Columbia in summer. Cont Shelf Res 25:1631-1656

> Hobday AJ, Boehlert GW (2001) The role of coastal ocean variation in spatial and temporal patterns in survival and size of coho salmon (Oncorhynchus kisutch). Can J Fish Aquat Sci 58:2021-2036

> Hooff RC, Peterson WT (2006) Copepod biodiversity as indicator of changes in ocean and climate conditions of the northern California current ecosystem. Limnol Oceanogr $51: 2607-2620$ 
Huyer A, Sobey E, Smith R (1979) The spring transition in currents over the Oregon continental shelf. J Geophys Res 84(C11):6995-7011

Jacobson K, Peterson B, Trudel M, Ferguson J and others (2012) The marine ecology of juvenile Columbia River Basin salmonids: a synthesis of research 1998-2011. Report of the US National Marine Fisheries Service, National Oceanic and Atmospheric Administration, Fisheries and Oceans Canada, Kintama Research Services, Ltd., and Oregon State University to Northwest Power and Conservation Council

> Johnson JB, Omland KS (2004) Model selection in ecology and evolution. Trends Ecol Evol 19:101-108

Koslow JA, Hobday AJ, Boehlert GW (2002) Climate variability and marine survival of coho salmon (Oncorhynchus kisutch) in the Oregon production area. Fish Oceanogr 11:65-77

Kutner MH, Nachtsheim CJ, Neter J, Li W (2005) Applied linear statistical models, 5th edn. McGraw-Hill Irwin, Boston, MA

> Lacroix GL, Knox D, McCurdy P (2004) Effects of dummy acoustic transmitters on juvenile Atlantic salmon. Trans Am Fish Soc 133:211-220

Lebreton J, Burnham KP, Clobert J, Anderson DR (1992) Modeling survival and testing biological hypotheses using marked animals: a unified approach with case studies. Ecol Monogr 62:67-118

> Logerwell EA, Mantua N, Lawson PW, Francis RC, Agostini VN (2003) Tracking environmental processes in the coastal zone for understanding and predicting Oregon coho (Oncorhynchus kisutch) marine survival. Fish Oceanogr 12:554-568

> Lyons DE, Roby DD, Collis K (2005) Foraging ecology of Caspian terns in the Columbia River estuary (USA). Waterbirds 28:280-291

- Mantua NJ, Hare SR, Zhang Y, Wallace JM, Francis RC (1997) A Pacific decadal climate oscillation with impacts on salmon. Bull Am Meteorol Soc 78:1069-1070

Martin P, Rancon J, Segura G, Dufour S, Laffont J, Boeuf G (2012) Experimental study of the influence of photoperiod and temperature on the swimming behaviour of hatchery-reared Atlantic salmon (Salmo salar L.) smolts. Aquaculture 362-363:200-208

Melnychuk MC, Christensen V, Walters CJ (2012) Mesoscale movement and mortality patterns of juvenile coho salmon and steelhead trout migrating through a coastal fjord. Environ Biol Fishes 96:325-339

Mesa MG, Warren JJ (1997) Predator avoidance ability of juvenile Chinook salmon subjected to sublethal exposures of gas supersaturated water. Can J Fish Aquat Sci 54:757-764

> Mesa MG, Weiland LK, Maule AG (2000) Progression and severity of gas bubble trauma in juvenile salmonids. Trans Am Fish Soc 129:174-185

Miller DR, Williams JG, Sims CW (1983) Distribution, abundance, and growth of juvenile salmonids off Oregon and Washington, summer 1980. Fish Res 2:1-17

> Moore ME, Berejikian BA, Tezak EP (2010) Early marine survival and behavior of steelhead smolts through Hood Canal and the Strait of Juan de Fuca. Trans Am Fish Soc 139:49-61

Morgan CA, De Robertis A, Zabel RW (2005) Columbia River plume fronts. I. Hydrography, zooplankton distribution, and community composition. Mar Ecol Prog Ser 299:19-31
Muir WD, Marsh DM, Sandford BP, Smith SS, Williams JG (2006) Post-hydropower system delayed mortality of transported Snake River stream-type Chinook salmon: unraveling the mystery. Trans Am Fish Soc 135:1523-1534

National Research Council (1996) Upstream: salmon and society in the Pacific Northwest. National Academy Press, Washington, DC

Pearcy WG (1992) Ocean ecology of North Pacific salmonids. Washington Sea Grant Program, Seattle, WA

> Peterson WT, Keister JE (2003) Interannual variability in copepod community composition at a coastal station in the northern California Current: a multivariate approach. Deep-Sea Res II 50:2499-2517

Peterson WT, Schwing FB (2003) A new climate regime in northeast Pacific ecosystems. Geophys Res Lett 30: 1896-1899

Peterson WT, Hooff RC, Morgan CA, Hunter KL, Casillas E, Ferguson JW (2006) Ocean conditions and salmon survival in the northern California Current. White Paper. Northwest Fisheries Science Center, Newport, RI. Available at: http://www.st.nmfs.noaa.gov/fate/documents/ ecosysrep.pdf (accessed 12 Nov 2013)

> Peterson WT, Morgan CA, Fisher JP, Casillas E (2010) Ocean distribution and habitat associations of yearling coho (Oncorhynchus kisutch) and Chinook (O. tshawytscha) salmon in the northern California Current. Fish Oceanogr 19:508-525

Porter AD, Welch DW, Rechisky EL, Jacobs MC, Winchell PM, Muirhead YK (2009a) Results from the POST pilotstage acoustic telemetry study on survival of Columbia River salmon, 2007. Report to the Bonneville Power Administration, Contract No. 32081, Project No. 2003114-00. Available at: http://pisces.bpa.gov/release/documents/documentviewer.aspx?doc=P114364 (accessed 12 November 2013)

Porter AD, Welch DW, Rechisky EL, Jacobs-Scott MC, Winchell PM, Muirhead YK (2009b) Results from the POST pilot-stage acoustic telemetry study on survival of Columbia River salmon, 2008. Report to the Bonneville Power Administration, Contract No. 00035492, Project No. 2003-114-00. Available at: http://pisces.bpa.gov/ release/documents/documentviewer.aspx?doc=P114363 (accessed 12 November 2013)

Porter AD, Welch DW, Rechisky EL, Jacobs-Scott MC and others (2010) Marine and freshwater measurement of delayed and differential-delayed mortality of Columbia \& Snake River yearling Chinook smolts using a continental-scale acoustic telemetry array, 2009. Report to the Bonneville Power Administration, Contract No. 46389, Project No. 2003-114-00. Available at: https://pisces. bpa.gov/release/documents/documentviewer.aspx?doc= P117408 (accessed 12 November 2013)

Porter AD, Welch DW, Rechisky EL, Challenger WO and others (2011) Marine and freshwater measurement of delayed and differential-delayed mortality of Columbia \& Snake River yearling Chinook smolts using a continental-scale acoustic telemetry array, 2010. Report to the Bonneville Power Administration, Contract No. 46389, Project No. 2003-114-00. Available at: http://pisces. bpa.gov/release/documents/documentviewer.aspx?doc= P122683 (accessed 12 November 2013)

Porter AD, Welch DW, Rechisky EL, Jacobs Scott MC, Winchell PM, Day J (2012a) Final report: key findings of the coastal ocean acoustic salmon tracking (COAST) project, 2006-2012. Report to the Bonneville Power Admin- 
istration, Contract No. 46389, Project No. 2003-114-00. Available at: http://pisces.bpa.gov/release/documents/ documentviewer.aspx? doc=P129415 (accessed 12 November 2013)

Porter AD, Welch DW, Rechisky EL, Jacobs-Scott MC, Winchell PM, Day J (2012b) Marine and freshwater measurement of delayed and differential-delayed mortality of Columbia \& Snake River yearling Chinook smolts using a continental-scale acoustic telemetry array, 2011. Report to the Bonneville Power Administration, Contract No. 52071, Project No. 2003-114-00. Available at: https://pisces.bpa.gov/release/documents/documentviewer.aspx?doc=P127340 (accessed 12 November 2013)

R Development Core Team (2011) R: a language and environment for statistical computing. Available at: www.rproject.org

Raiffa H, Schlaifer R (1961) Applied statistical decision theory. Harvard University Press, Cambridge, MA

Rechisky EL, Welch DW (2010) Surgical implantation of acoustic tags: influence of tag loss and tag-induced mortality on free-ranging and hatchery-held spring Chinook (O. tschawytscha) smolts. In: Wolf KS, O'Neal JS (eds) PNAMP special publication: tagging, telemetry and marking measures for monitoring fish populations - a compendium of new and recent science for use in informing technique and decision modalities. Special Publication 2010-002, Pacific Northwest Aquatic Monitoring Partnership, p 69-94. Available at: www.pnamp. org/node/2890

Rechisky EL, Welch DW, Porter AD, Jacobs MC, Ladouceur A (2009) Experimental measurement of hydrosysteminduced delayed mortality in juvenile Snake River spring Chinook salmon (Oncorhynchus tshawytscha) using a large-scale acoustic array. Can J Fish Aquat Sci 66: 1019-1024

Rechisky EL, Welch DW, Porter AD, Jacobs-Scott MC, Winchell PM, McKern JL (2012) Estuarine and early-marine survival of transported and in-river migrant Snake River spring Chinook salmon smolts. Sci Rep 2:448

> Rechisky EL, Welch DW, Porter AD, Jacobs-Scott MC, Winchell PM (2013) Influence of multiple dam passage on survival of juvenile Chinook salmon in the Columbia River estuary and coastal ocean. Proc Natl Acad Sci USA 110:6883-6888

Rechisky EL, Welch DW, Porter AD, Hess JE, Narum SR (2014) Testing for delayed mortality effects in the early marine life history of Columbia River Basin yearling Chinook salmon. Mar Ecol Prog Ser 496:159-180

Ritz C, Streibig JC (2008) Nonlinear regression with R. Springer, New York, NY

Roby DD, Collis K, Lyons DE, Craig DP, Adkins JY, Myers AM, Suryan RM (2002) Effects of colony relocation on diet and productivity of Caspian terns. J Wildl Manag 66: 662-673

Ryding KE, Skalski JR (1999) Multivariate regression relationships between ocean conditions and early marine survival of coho salmon (Oncorhynchus kisutch). Can J Fish Aquat Sci 56:2374-2384

Submitted: March 13, 2013; Accepted: September 2, 2013
Schaller HA, Petrosky CE (2007) Assessing hydrosystem influence on delayed mortality of Snake River streamtype Chinook salmon. N Am J Fish Manag 27:810-824

> Scheuerell MD, Williams JG (2005) Forecasting climateinduced changes in the survival of Snake River spring/ summer Chinook salmon (Oncorhynchus tshawytscha). Fish Oceanogr 14:448-457

Scheuerell MD, Zabel RW, Sandford BP (2009) Relating juvenile migration timing and survival to adulthood in two species of threatened Pacfic salmon (Oncorhynchus spp.). J Appl Ecol 46:983-990

> Schwing FB, Bond NA, Bograd SJ, Mitchell T, Alexander MA, Mantua N (2006) Delayed coastal upwelling along the U.S. West Coast in 2005: a historical perspective. Geophys Res Lett 33:L22S01, doi:10.1029/2006GL026911

Sykes GE, Shrimpton JM (2010) Effect of temperature and current manipulation on smolting in Chinook salmon (Oncorhynchus tshawytscha): the relationship between migratory behaviour and physiological development. Can J Fish Aquat Sci 67:191-201

Thorstad EB, Whoriskey F, Uglem I, Moore A, Rikardsen AH, Finstad B (2012) A critical life stage of the Atlantic salmon Salmo salar: behaviour and survival during the smolt and initial post-smolt migration. J Fish Biol 81:500-542

Tomaro LM, Teel DJ, Peterson WT, Miller JA (2012) When is bigger better? Early marine residence of middle and upper Columbia River spring Chinook salmon. Mar Ecol Prog Ser 452:237-252

USACOE (US Army Corp of Engineers) (2011) Dissolved gas and water temperature report. USACOE, Northwestern Division, Columbia Basin Water Management Division, Reservoir Control Center, Water Quality Unit. Available at: www.nwd-wc.usace.army.mil/tmt/wqnew/tdg_and_temp/ 2011/ (accessed 12 November 2013)

USNARA (US National Archives and Records Administration) (2012) Code of Federal Regulations Title 55. Endangered and threatened wildlife. Section 17.11

Welch DW, Melnychuk MC, Rechisky ER, Porter AD and others (2009) Freshwater and marine migration and survival of endangered Cultus Lake sockeye salmon smolts using POST, a large-scale acoustic telemetry array. Can J Fish Aquat Sci 66:736-750

> Welch DW, Melnychuk MC, Payne JC, Rechisky EL and others (2011) In situ measurement of coastal ocean movements and survival of juvenile Pacific salmon. Proc Natl Acad Sci USA 108:8708-8713

White GC, Burnham KP (1999) Program MARK: survival estimation from populations of marked animals. Bird Study 46(Suppl):120-138

Williams BK, Eaton M, Breininger D (2011) Adaptive resource management and the value of information. Ecol Model 222:3429-3436

Yakima Nation (2011) Yakima/Klickitat fisheries project monitoring and evaluation for the performance period May 1, 2010 through April 30, 2011. Final Report to the Bonneville Power Administration, Contract No. 00042445, Project No. 1995-063-25. Available at: http:// pisces.bpa.gov/release/documents/documentviewer.aspx? doc $=$ P122475 (accessed 12 Nov 2013)

Proofs received from author(s): November 13, 2013 